\title{
Peningkatan Hasil Belajar dan Minat Belajar Matematika Materi Bangun Ruang Sisi Lengkung melalui Pembelajaran Kooperatif Tipe Student Teams Achievment Divisions pada Siswa Kelas IXA SMP Negeri 4 Bumijawa
}

\author{
Maprokhi \\ Guru Matematika SMP Negeri 4 Bumijawa Kabupaten Tegal Provinsi Jawa Tengah \\ maprokhi@gmail.com
}

\begin{abstract}
Abstrak - Tujuan dari penelitian ini adalah untuk meningkatkan hasil belajar dan minat belajar matematika materi bangun ruang sisi lengkung melalui pembelajaran kooperatif tipe Student Teams Achievement Divisions (STAD) pada siswa kelas IXA SMP Negeri 4 Bumijawa Semester 1 Tahun Pelajaran 2017/2018. Jenis penelitian ini adalah penelitian tindakan kelas menggunakan pembelajaran kooperatif tipe Student Teams Achievement Divisions (STAD) yang terdiri dari lima komponen: (1) presentasi kelas, (2) tim (kelompok), (3) kuis, (4) skor kemajuan individu, dan (5) rekognisi tim (penghargaan kelompok). Penelitian dilaksanakan di Kelas IXA SMP Negeri 4 Bumijawa Kabupaten Tegal dengan subjek penelitian sebanyak 20 siswa. Instrumen pengumpulan data pada penelitian tindakan kelas ini adalah instrumen pengukuran hasil belajar berupa instrumen tes tertulis berbentuk uraian, instrumen pengukuran minat belajar matematika berupa angket, dan lembar observasi keterlaksanaan pembelajaran. Hasil penelitian menunjukkan bahwa: rata-rata nilai hasil belajar meningkat dari 49,95 pada kondisi awal menjadi 63,8 pada siklus I dan 83 pada siklus II. Persentase siswa yang tuntas belajar juga mengalami peningkatan dari $20 \%$ pada kondisi awal menjadi $40 \%$ pada siklus I dan $80 \%$ pada siklus II. Rata-rata skor minat belajar matematika juga mengalami peningkatan dari 64,85 (kategori rendah) pada siklus I menjadi 75,85 (kategori sedang) pada siklus I dan 94,25 (kategori tinggi) pada siklus II. Persentase siswa yang mendapatkan skor minat belajar matematika minimal tinggi (tinggi dan sangat tinggi) mengalami peningkatan dari 15\% pada kondisi awal menjadi $30 \%$ pada siklus I dan $85 \%$ pada siklus II. Sementara untuk rata-rata persentase keterlaksanaan pembelajaran menggunakan pembelajaran kooperatif tipe STAD juga mengalami peningkatan dari 79,63\% (kriteria cukup) pada siklus I menjadi 93,52\% (kriteria sangat tinggi) pada siklus II. Karena indikator keberhasilan/indikator kinerja telah dipenuhi semua pada siklus II, maka penelitian dikatakan berhasil dan tidak dilanjutkan ke siklus selanjutnya. Sehingga dapat disimpulkan bahwa pembelajaran kooperatif tipe STAD dapat meningkatkan hasil belajar dan minat belajar matematika materi bangun ruang sisi lengkung pada siswa kelas IXA SMP Negeri 4 Bumijawa semester 1 tahun pelajaran 2017/2018.
\end{abstract}

Kata Kunci: PTK, kooperatif, STAD, hasil belajar, minat belajar 


\section{PENDAHULUAN}

Matematika telah digunakan di berbagai bidang. Berbagai macam bidang pekerjaan menggunakan matematika dalam kegiatannya seperti bidang konstruksi, manufaktur, perdagangan maupun bidang pekerjaan yang bersifat profesi seperti ilmuwan, perekayasa dan dokter tidak lepas dari matematika. Selain itu matematika merupakan dasar bagi mata pelajaran lain terutama untuk mata pelajaran sains dan ekonomi, oleh karena itu matematika diajarkan mulai dari sekolah dasar (SD) sampai dengan perguruan tinggi. Matematika juga dijadikan salah satu indikator kemajuan pendidikan suatu negara seperti pencapaian dalam TIMMS, PISA, atau lomba olimpiade matematika tingkat internasional.

Namun demikian, pelaksanaan pembelajaran matematika di kelas sebagian besar masih mengalami masalah. Permasalahan yang muncul di lapangan sangatlah beragam, misalnya permasalahan rendahnya hasil dan minat belajar matematika siswa, penggunaan metode pembelajaran yang kurang tepat, dan kondisi lingkungan belajar yang kurang kondusif. Oleh karena itu, guru perlu melakukan suatu tindakan yang dapat mengatasi berbagai masalah yang muncul di kelas-kelas mereka.

Berbagai masalah tersebut di atas juga terjadi di SMP Negeri 4 Bumijawa Kabupaten Tegal. Secara umum hasil belajar matematika siswa di SMP Negeri 4 Bumijawa masih rendah. Sebagai gambaran, pada tahun pelajaran 2017/2018 ini, berdasarkan analisis ulangan harian siswa kelas IXA menunjukkan bahwa rata-rata nilai siswa adalah 49,95 jauh dari KKM yang ditentukan yaitu 72 dan siswa yang tuntas hanya 4 siswa dari 20 siswa atau hanya $20 \%$.
Selain permasalahan hasil belajar yang relatif rendah, permasalahan lain yang muncul dalam pembelajaran matematika adalah masalah minat belajar matematika siswa yang masih perlu ditingkatkan. Minat yang rendah siswa terhadap mata pelajaran matematika dapat terlihat ketika proses pembelajaran berlangsung siswa masih banyak yang tidak menyimak pembelajaran dengan baik. Hal ini ditandai dengan masih adanya siswa yang berbicara dengan teman sebangku, bermain sendiri, mengantuk, menggambar dan acuh dengan penjelasan guru. Hasil pengamatan peneliti juga menunjukkan bahwa catatan pelajaran matematika masih banyak yang tidak lengkap. Kurangnya minat siswa terhadap mata pelajaran matematika juga dipengaruhi oleh stigma bahwa matematika merupakan pelajaran yang sulit dan tidak bisa diterapkan pada kehidupan nyata. Secara kuantitatif untuk mengukur minat belajar matematika, peneliti menggunakan angket yang telah diisi oleh siswa. Hasil menunjukkan bahwa skor rata-rata minat belajar matematika siswa kelas IXA adalah 64,85 termasuk kategori rendah dengan rincian 3 siswa berkategori tinggi (15\%), 5 siswa berkategori sedang (25\%), 7 siswa berkategori rendah $(35 \%)$ dan 5 siswa berkategori sangat rendah $(25 \%)$.

Rendahnya hasil dan minat belajar matematika siswa ini diduga karena dalam pembelajaran peneliti masih dominan menggunakan metode konvensional yaitu metode ceramah. Pembelajaran dilakukan dengan cara satu arah dengan berpusat pada guru (teacher centered). Siswa kurang diberi kesempatan untuk membangun pengetahuannya sendiri. Siswa kurang diberi ruang untuk melakukan tanya jawab baik dengan guru maupun dengan sesama siswa. Interaksi 
antarsiswa dalam proses pembelajaran juga sangat kurang sehingga kerjasama siswa dalam membangun pengetahuannya juga kurang. Peneliti juga kurang memberi penguatan terutama penguatan positif pada siswa jika siswa mampu menjawab soal-soal latihan dengan betul. Refleksi kegiatan pembelajaran yang telah dilakukan dengan membuat kesimpulan yang dilakukan oleh siswa juga tidak maksimal.

Berdasarkan uraian di atas, peneliti menerapkan pembelajaran kooperatif tipe Student Teams Achievement Divisions (STAD) sebagai upaya meningkatkan hasil belajar dan minat belajar matematika materi bangun ruang sisi lengkung siswa kelas IXA SMP Negeri 4 Bumijawa. Firmanto \& Sapti (2013: 1) melakukan penelitian tindakan kelas dengan judul Meningkatkan Minat dan Hasil Belajar Matematika Melalui Metode STAD Menggunakan LKS Berbasis PMR. Penelitian ini dilakukan di kelas VIIF SMP Negeri 22 Kabupaten Purworejo Provinsi Jawa Tengah. Hasil penelitian menunjukkan bahwa minat dan hasil belajar matematika mengalami peningkatan. Hal ini ditunjukkan dengan adanya peningkatan persentase minat belajar matematika siswa dari siklus I ke siklus II. Untuk peningkatan persentase ratarata minat belajar matematika dari siklus I ke siklus II yaitu $65 \%$ dengan kriteria "tinggi" menjadi $84 \%$ dengan kriteria "sangat tinggi". Hasil belajar matematika siswa mengalami peningkatan dari $22,36 \%$ pada kemampuan awal menjadi $77,42 \%$ pada siklus I dan meningkat menjadi $80,64 \%$ pada siklus II.

\section{KAJIAN LITERATUR}

Menurut Shadiq dalam Sardin \& Sunandar (2018: 2), matematika diberikan untuk membekali siswa dengan kemampuan berpikir logis, analitis, sistematis, kritis, dan kreatif. Matematika merupakan sarana untuk menanamkan kebiasaan menggunakan penalaran dalam pola pikir seseorang. Semua siswa harus memiliki kesempatan dan dukungan yang diperlukan untuk dapat belajar matematika secara mendalam dan disertai dengan pemahaman (Sardin \& Sunandar, 2018:2). Kemampuan tersebut dapat diperoleh siswa jika siswa mendapatkan pembelajaran matematika yang dapat mendukung siswa mencapai tujuan tersebut. Sutherland (2007: 32) menyatakan bahwa belajar matematika adalah belajar tentang penggunaan alat-alat baru yang memungkinkan untuk menyelesaikan masalah yang akan sulit atau tidak mungkin untuk menyelesaikan dengan alat yang lama. Hal ini menunjukan bahwa belajar matematika adalah belajar menemukan solusi dari permasalahan yang dihadapi terkait dengan matematika. Selanjutnya NCTM (2000: 16) menyatakan bahwa pengajaran matematika yang efektif, guru harus mengerti apa yang siswa ketahui dan butuhkan dalam belajar matematika, kemudian memberikan tanggapan dan mendukung siswa untuk belajar dengan baik.

Peraturan Menteri Pendidikan dan Kebudayaan Nomor 58 Tahun 2014 tentang Kurikulum 2013 Sekolah Menengah Pertama/Madrasah Tsanawiyah pada bagian Pedoman Mata Pelajaran (PMP) Matematika menyebutkan ada enam karakteristik matematika: (1) objek yang dipelajari abstrak, (2) kebenarannya berdasarkan logika, (3) pembelajarannya secara bertingkat dan kontinu, (4) ada keterkaitan antara materi yang satu dengan yang lainnya, (5) menggunakan 
bahasa simbol, (6) diaplikasikan di bidang ilmu lain.

Selanjutnya disebutkan juga ruang lingkup pembelajaran matematika di SMP/MTs adalah sebagai berikut: (1) konsep, operasi dan pola bilangan, (2) aljabar dan relasi, (3) geometri dan pengukuran, (4) statistika dan peluang.

Bangun ruang sisi lengkung adalah materi mata pelajaran matematika yang merupakan bagian dari materi geometri. Geometri penting dipelajari di sekolah karena geometri merupakan salah satu cabang matematika yang sangat esensial dan sangat terkait dengan kehidupan. Menurut NCTM (2000: 41). Siswa seringkali bersentuhan dengan benda-benda sebagai representasi dari bentuk-bentuk geometri yang dipelajari di sekolah khususnya bangun ruang sisi lengkung (tabung, kerucut, dan bola).

Aspek penting dari geometri adalah membangun dan memanipulasi pikiran melalui objek berdimensi dua dan tiga, serta memahami objek dari sudut pandang yang berbeda (NCTM, 2000: 41). Oleh sebab itu, dalam pembelajaran geometri perlu model, pendekatan, metode, maupun strategi pembelajaran yang tepat sehingga tercipta pembelajaran yang lebih efektif untuk meningkatkan hasil belajar dan minat belajar siswa.

Menurut Nitko \& Brookhart (2011: 497), hasil belajar merupakan pengetahuan, keterampilan dan kemampuan yang telah dikembangkan siswa sebagai hasil proses pembelajaran. Sedangkan minat didefinisikan oleh Collete \& Chiappetta (1994: 74) sebagai keingintahuan atau daya tarik pada suatu pemikiran atau kejadian yang melibatkan perhatian. Sedangkan menurut Slameto (2010: 180) minat adalah suatu rasa lebih suka dan rasa ketertarikan pada suatu hal atau aktivitas, tanpa ada yang menyuruh.

Menurut Slavin (2010: 4) pembelajaran kooperatif merujuk pada berbagai macam metode pengajaraan di mana para siswa bekerja dalam kelompok-kelompok kecil untuk saling membantu satu sama lainnya dalam mempelajari materi pelajaran. Dalam kelas kooperatif, para siswa diharapkan dapat saling membantu, saling mendiskusikan dan berargumentasi, untuk mengasah pengetahuan yang mereka kuasai saat itu dan menutup kesenjangan dalam pemahaman masing-masing. Selanjutnya Slavin (2010: 4) menyatakan bahwa pembelajaran kooperatif dapat meningkatkan prestasi/hasil belajar siswa. Karena pemberian penghargaan pada pembelajaran kooperatif, siswa dapat melakukan lebih baik dari apa yang dilakukan sebelumnya dan siswa lebih termotivasi untuk berusaha. Karakteristik pembelajaran kooperatif menurut Slavin (2010: 26) adalah sebagai berikut: (1) tujuan kelompok, (2) tanggung jawab individual, (3) kesempatan sukses yang sama, (4) kompetisi kelompok, (5 spesialisasi tugas, dan (6 adaptasi terhadap kebutuhan kelompok.

Salah satu tipe pembelajaran kooperatif yang banyak digunakan dalam kegiatan pembelajaran adalah tipe Student Teams Achivement Divisions (STAD). Menurut Slavin (2010: 143), STAD terdiri atas lima komponen utama, yaitu: (1) presentasi kelas, (2) Tim (kelompok), (3) kuis, (4) skor kemajuan individual, dan (5) rekognisi tim ( penghargaan kelompok)

Kelompok akan mendapatkan sertifikat atau bentuk penghargaan yang lain apabila skor rata-rata mereka mencapai kriteria tertentu. Cara menentukan skor dalam pendekatan pembelajaran kooperatif adalah dengan 
mencatat skor awal, yaitu skor siswa sebelum pembelajaran atau skor kuis sebelumnya. Skor kemajuan ditentukan dengan membandingkan skor awal dan skor kuis dengan ketentuan sebagai mana dituliskan dalam Tabel 1.

Tabel 1. Daftar Poin Kemajuan Individu

\begin{tabular}{|c|c|c|}
\hline \multicolumn{3}{|l|}{ Skor Kuis } \\
\hline \multicolumn{3}{|c|}{$\begin{array}{l}\text { Lebih dari } 10 \text { poin di } \\
\text { bawah skor awal }\end{array}$} \\
\hline \multicolumn{3}{|c|}{$\begin{array}{l}10 \text { - } 1 \text { di bawah skor } \\
\text { awal }\end{array}$} \\
\hline \multicolumn{3}{|c|}{ Skor awal sampai 10} \\
\hline \multicolumn{2}{|c|}{$\begin{array}{l}\text { Lebih dari } 10 \text { poin di atas } \\
\text { skor awal }\end{array}$} & 30 \\
\hline \multicolumn{2}{|c|}{$\begin{array}{l}\text { Kertas jawaban } \\
\text { sempurna (terlepas dari } \\
\text { skor awal }\end{array}$} & \\
\hline \multicolumn{3}{|c|}{ Sumber: Slavin (2010: 159) } \\
\hline \multicolumn{3}{|c|}{$\begin{array}{c}\text { Secara lengkap } \\
\text { penghargaan kriteria } \\
\text { pembelajaran kooperatif terdiri dari } \\
\text { tiga tingkatan penghargaan } \\
\text { berdasarkan skor rata-rata kelompok } \\
\text { atau tim seperti terlihat pada Tabel } 2 \text {. } \\
\text { Tabel 2. Kriteria Penghargaan } \\
\text { Kelompok }\end{array}$} \\
\hline $\begin{array}{c}\text { Kriteria } \\
\text { (rata-rata tim) }\end{array}$ & Pel & nghargaan \\
\hline$\leq 15$ & & $\begin{array}{l}\text { m baik } \\
\text { od team) }\end{array}$ \\
\hline $16-19$ & $\begin{array}{r}\text { Tim sa } \\
\text { (gres }\end{array}$ & $\begin{array}{l}\text { angat baik } \\
\text { at team) }\end{array}$ \\
\hline$\geq 20$ & & $\begin{array}{l}\text { n super } \\
\text { ser team) }\end{array}$ \\
\hline
\end{tabular}

Sumber: Diadopsi dan diadaptasi dari Slavin (2010: 160)

\section{METODE PENELITIAN \\ Jenis Penelitian}

Copyright @2018, Jurnal Didactical Mathematics
Penelitian ini adalah penelitian tindakan kelas yang dilaksanakan mengikuti tahap-tahap penelitian sebagaimana dikemukakan oleh Kemmis dan Mc Taggart (Hopkins, 2008: 51). Adapun tahap-tahap tersebut adalah perencanaan (plan), tindakan (act), pengamatan (observe), dan refleksi (reflect).

\section{Waktu dan Tempat Penelitian}

Penelitian dilaksanakan di SMP Negeri 4 Bumijawa Kabupaten Tegal Provinsi Jawa Tengah pada bulan Juli Desember 2017.

\section{Subjek Penelitian}

Subjek penelitian dalam penelitian ini adalah siswa kelas IXA SMP Negeri 4 Bumijawa tahun pelajaran 2017/2018. Banyak siswa sebagai subjek penelitian di kelas IXA adalah 20 siswa yang terdiri dari 8 siswa laki-laki dan 12 siswa perempuan.

\section{Prosedur Penelitian}

Prosedur penelitian mengacu pada tahap-tahap penelitian sebagaimana dikemukakan oleh Kemmis dan Mc Taggart (Hopkins, 2008: 51) seperti pada gambar 1.

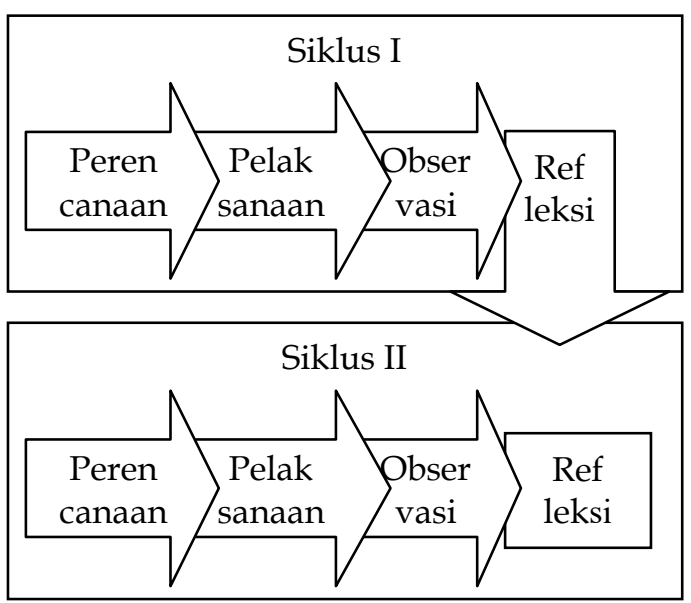

Gambar 1. Siklus Penelitian Tindakan Sumber: Diadopsi dan diadaptasi dari Kemmis \& Mc Taggart dalam Hopkins, (2008: 51) 


\section{Data, Instrumen, dan Teknik Pengumpulan Data}

Jenis data dalam penelitian ini adalah data kualitatif dan data kuantitatif. Data kualitatif diperoleh dari komentar dan saran observer mengenai keterlaksanaan pembelajaran. Data kuantitatif diperoleh dari skor hasil belajar siswa, skor minat belajar siswa, dan hasil observasi keterlaksanaan pembelajaran.

Instrumen yang digunakan pada penelitian ini adalah: (1) instrumen pengukuran hasil belajar, (2) instrumen pengukuran minat belajar, dan (3) lembar observasi keterlaksanaan pembelajaran.

Teknik pengumpulan data pada penelitian ini menggunakan teknik angket, observasi, dan pengukuran dengan tes. Teknik angket digunakan untuk mengumpulkan data minat belajar siswa. Teknik observasi digunakan untuk mengumpulkan data keterlaksanaan pembelajaran. Teknik tes digunakan untuk mengumpulkan data hasil belajar siswa.

\section{Teknik Analisis Data}

Analisis data dalam penelitian ini bertujuan untuk menjawab pertanyaan penelitian. Data yang berupa saran dan komentar dari observer setiap siklus dianalisis secara deskriptif kualitatif dan disimpulkan sebagai masukan untuk perbaikan pembelajaran pada siklus berikutnya. Sedangkan, data yang berupa skor hasil belajar siswa, skor minat belajar siswa dan persentase observasi keterlaksanaan pembelajaran dianalisis secara deskriptif kuantitatif untuk mengetahui tingkat keberhasilan penelitian berdasarkan kriteria yang telah ditetapkan. Teknik analisis secara rinci adalah sebagai berikut:

Teknik Analisis Data Hasil belajar
Siswa dikatakan tuntas secara individual jika siswa mencapai atau melampaui Kriteria Ketuntasan Minimal (KKM) yaitu 72. Sedangkan ketuntasan secara klasikal, jika paling sedikit $75 \%$ siswa subjek penelitian mencapai kriteria ketuntasan individual.

\section{Analisis Data Minat Belajar Siswa}

Analisis data minat belajar siswa dilakukan dengan menghitung skor empirik dari masing-masing siswa, kemudian mengkonversi ke dalam data kualitatif. Kriteria skor minat belajar matematika siswa dapat dilihat seperti pada Tabel 3.

Tabel 3. Kriteria Skor Minat Belajar Siswa

\begin{tabular}{cc}
\multicolumn{2}{c}{ Siswa } \\
\hline Interval Skor & Kategori \\
\hline$x>105$ & Sangat Tinggi \\
$85<x \leq 105$ & Tinggi \\
$65<x \leq 85$ & Sedang \\
$45<x \leq 65$ & Rendah \\
$x \leq 45$ & Sangat Rendah \\
\hline
\end{tabular}

Sumber: Diadopsi dan diadaptasi dari Widoyoko (2014: 238)

Analisis Data Observasi Keterlaksanaan Kegiatan Pembelajaran

Data yang diperoleh dari observasi keterlaksanaan kegiatan pembelajaran dihitung persentase keterlaksanaannya untuk setiap pertemuan, dengan cara sebagai berikut:

$$
P=\frac{M}{T} \times 100 \%
$$

Keterangan:

$$
\begin{aligned}
& P= \text { Persentase keterlaksanaan setiap } \\
& \text { pertemuan pembelajaran } \\
& M= \begin{array}{l}
\text { Jumlah skor untuk setiap } \\
\text { pertemuan pembelajaran }
\end{array}
\end{aligned}
$$


$T=$ Jumlah skor maksimum ideal untuk setiap pertemuan pembelajaran

Setelah diperoleh persentase keterlaksanaan pembelajaran setiap pertemuan, kemudian dihitung ratarata keterlaksanaan pembelajaran setiap siklusnya. Kriteria keterlaksanaan pembelajaran tercantum pada Tabel 4.

Tabel 4. Kriteria Keterlaksanaan Pembelajaran

\begin{tabular}{cl}
\hline Interval $(\%)$ & \multicolumn{1}{c}{ Kriteria } \\
\hline $90<P \leq 100$ & Sangat baik \\
$80<P \leq 90$ & Baik \\
$70<P \leq 80$ & Cukup \\
$P \leq 70$ & Kurang \\
\hline
\end{tabular}

Sumber: Diadopsi dan diadaptasi dari Kemdikbud (2014: 165)

\section{Indikator Keberhasilan/Kinerja}

Penelitian dikatakan berhasil jika memenuhi kriteria sebagai berikut: (1) rata-rata hasil belajar siswa mencapai 72 atau lebih ( $\geq 72)$, (2) paling sedikit $75 \%(\geq 75 \%)$ siswa mencapai atau melebihi Kriteria Ketuntasan Minimal (KKM) yang ditetapkan yaitu 72, (3) rata-rata skor minat belajar matematika siswa lebih dari 85 (> 85), (4) siswa yang memiliki skor minat belajar matematika minimal kategori tinggi (tinggi dan sangat tinggi) lebih dari 80\% (>80\%), (5) keterlaksanaan pembelajaran menggunakan pembelajaran kooperatif tipe STAD minimal mencapai kriteria baik.

\section{HASIL DAN PEMBAHASAN}

\section{Analisis Data Hasil Belajar}

Rata-rata nilai hasil belajar siklus I dan siklus II kelas IXA SMP Negeri 4
Bumijawa dapat digambarkan seperti pada Grafik 1.

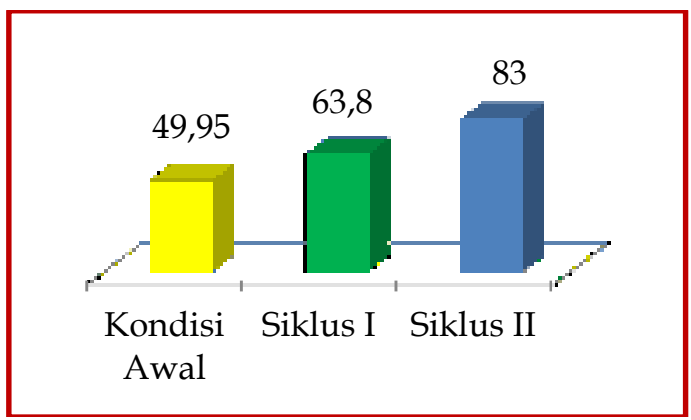

Grafik 1. Rata-rata Nilai Hasil Belajar

Grafik 1 menunjukkan bahwa ratarata nilai hasil belajar siswa mengalami peningkatan dari 49,95 menjadi 63,8 pada siklus I dan 83 pada siklus II. Sementara untuk ketuntasan hasil belajar siswa dapat dilihat seperti pada Grafik 2.

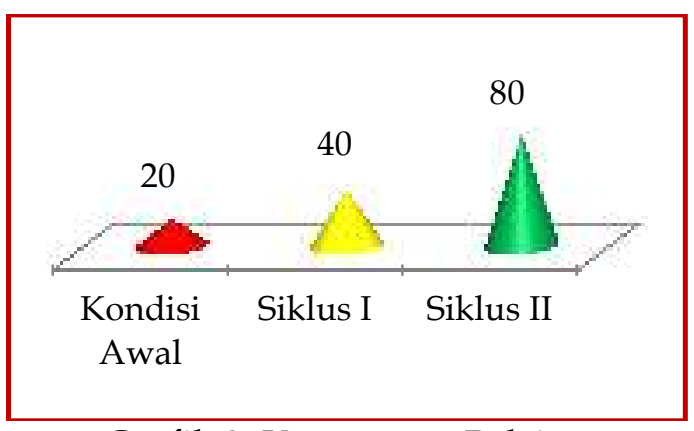

Grafik 2. Ketuntasan Belajar

Grafik 2 menunjukkan bahwa persentase siswa yang tuntas belajar mengalami peningkatan dari $20 \%$ pada kondisi awal menjadi $40 \%$ pada siklus I dan $80 \%$ pada siklus II.

\section{Minat Belajar Matematika}

Rata-rata skor minat belajar matematika pada kondisi awal, siklus I dan siklus II kelas IXA SMP Negeri 4 Bumijawa dapat digambarkan seperti pada Grafik 3. 


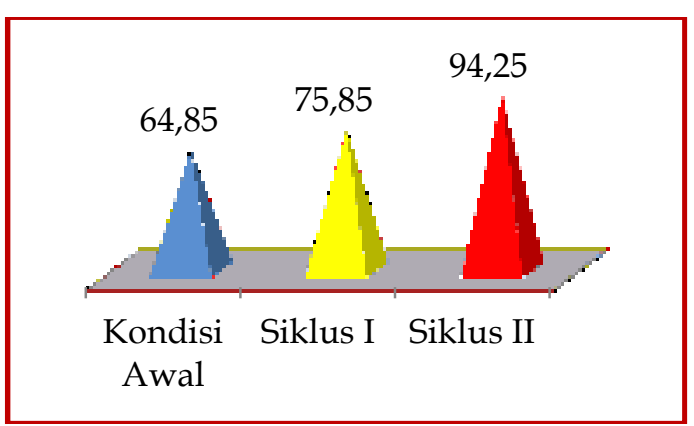

Grafik 3. Rata-rata Skor Minat Belajar Matematika

Grafik 3 menunjukkan bahwa ratarata skor minat belajar matematika siswa meningkat dari 64,85 (kategori rendah) pada kondisi awal menjadi 75,85 (kategori sedang) pada siklus I dan 94,25 (kategori tinggi) pada siklus II.

Persentase siswa yang memperoleh skor minat belajar matematika minimal tinggi (tinggi dan sangat tinggi) dapat dilihat seperti pada Grafik 4.

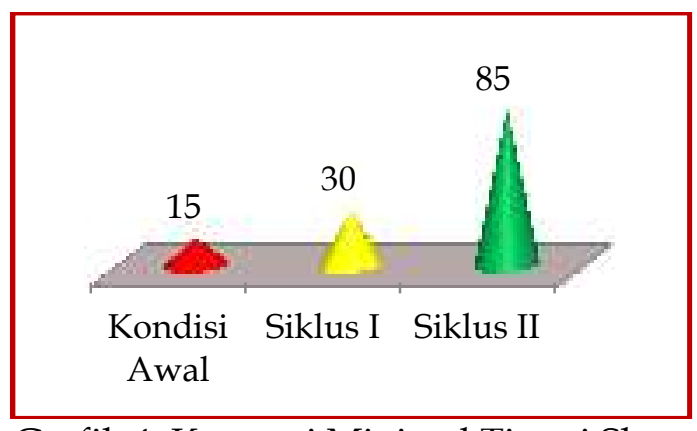

Grafik 4. Kategori Minimal Tinggi Skor

Minat Belajar Matematika

Grafik 4 menunjukkan bahwa persentase siswa dengan skor minat belajar matematika berkategori minimal tinggi (tinggi dan sangat tinggi) mengalami peningkatan dari $15 \%$ pada kondisi awal menjadi $30 \%$ pada siklus I dan $85 \%$ pada siklus II.

\section{Analisis Data Keterlaksanaan Pembelajaran}

Rata-rata persentase keterlaksanaan pembelajaran menggunakan pembelajaran kooperatif tipe STAD siklus I dan siklus II di kelas IXA SMP Negeri 4 Bumijawa dapat digambarkan seperti pada Grafik 5.

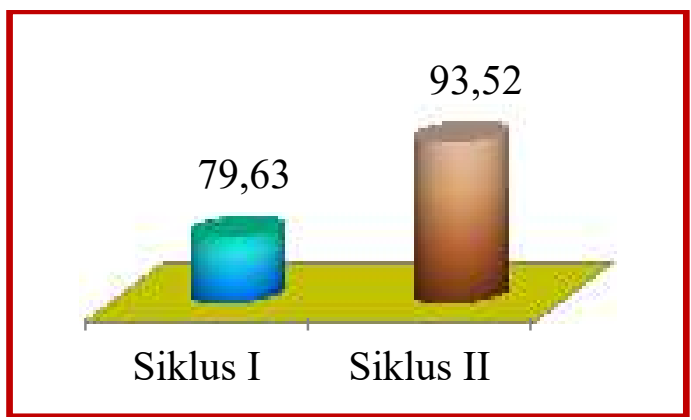

Grafik 6. Rata-rata Persentase

Keterlaksanaan Pembelajaran

Grafik 5 menunjukkan bahwa ratarata persentase keterlaksanaan pembelajaran menggunakan pembelajaran kooperatif tipe STAD mengalami peningkatan dari 79,63\% (kriteria cukup) pada siklus I menjadi 93,52\% (kriteria sangat baik) pada siklus II.

\section{Pembahasan Siklus I}

Kegiatan pembelajaran pada siklus I secara umum dapat berjalan sesuai dengan langkah yang dirancang dalam RPP. Namun masih terdapat kegiatan pembelajaran khususnya karakteristik pembelajaran kooperatif tipe STAD yang belum muncul dengan maksimal, diantaranya yaitu: (1) tanggung jawab siswa dalam kelompoknya masingmasing, (2) ketergantungan positif antarsiswa, (3) partisipasi siswa dalam kelompok, (4) keterampilan sosial siswa dalam kelompok, (5) pemberian masukan dan tanggapan dari kelompok bukan penyaji, dan (6) merangkum dan menyimpulkan isi pembelajaran.

Beberapa kendala yang menyebabkan beberapa langkah kegiatan pembelajaran tidak terlaksana dengan maksimal seperti yang telah disebutkan di atas adalah: (1) kemampuan prasyarat siswa masih 
rendah sehingga waktu terbuang untuk mengecek kembali kemampuan prasyarat siswa, (2) siswa masih belum terbiasa belajar dengan pembelajaran kooperatif/kelompok sehingga perlu penyesuaian yang agak lama, (3) masih terdapat siswa yang bermain sendiri ketika diskusi, (4) masih terdapat siswa yang bercanda atau berbicara dengan temannya yang tidak ada hubungannya dengan kegiatan belajar, (5) masih banyaknya siswa yang menunggu hasil pekerjaan teman dan menyalinnya pada buku catatannya, (6) LKS hanya dikerjakan sendiri oleh siswa dengan kompetensi tinggi tidak dengan diskusi bersama anggota kelompoknya, hal ini disebabkan karena LKS dibagikan satu kelompok satu LKS, dan (7) manajemen waktu oleh peneliti masih kurang efektif.

Di akhir siklus I, kegiatan kuis/ulangan harian dapat terlaksana. Pengamatan peneliti pada kegiatan kuis pada siklus I ini, siswa masih banyak yang tidak konsentrasi dalam mengerjakan soal. Masih banyak siswa yang menengok temannya dengan harapan mendapatkan jawaban dari temannya. Nilai hasil kuis ini selanjutnya diolah untuk mendapatkan skor kemajuan individual masingmasing siswa. Kemudian dihitung ratarata skor untuk setiap kelompok dan hasilnya untuk menentukan penghargaan kepada setiap kelompok berdasarkan kriteria yang telah ditentukan. Pemberian penghargaan dilaksanakan dengan memberikan piagam kepada kelompok yang mendapatkan kategori tim super. Sedangkan untuk kelompok dengan kategori tim sangat baik dan baik tidak mendapatkan piagam. Hal ini dimaksudkan agar anggota kelompok dari kelompok yang berkategori sebagai tim sangat baik dan baik dapat belajar dengan sungguh-sungguh dan berusaha menjadi lebih baik sehingga nilainya meningkat agar mendapatkan piagam dengan penghargaan sebagai tim super. Pada siklus I ini terdapat tiga kelompok yang mendapatkan penghargaan sebagai tim super.

Indikator keberhasilan/indikator kinerja pada siklus I dapat dirinci seperti berikut: (1) rata-rata hasil belajar siswa adalah 63,8 belum mencapai atau melampaui target yang diharapkan yaitu 72, (2) persentase siswa yang mencapai atau melampaui KKM adalah $40 \%$ belum mencapai atau melampaui target yang diharapkan yaitu 75\%, (3) rata-rata skor minat belajar matematika siswa adalah 75,85 (kategori sedang) masih belum memenuhi target yang diharapkan yaitu lebih dari 85 (kategori minimal tinggi), persentase siswa yang memiliki skor minat belajar matematika kategori minimal tinggi (tinggi dan sangat tinggi) adalah 30\% masih di bawah target yang diharapkan yaitu lebih dari $80 \%$, (5) rata-rata persentase menggunakan pembelajaran kooperatif tipe STAD baru mencapai 79,63\% termasuk kategori cukup, sehingga keterlaksanaan pembelajaran belum mencapai atau melampaui target yang ditentukan yaitu minimal kategori baik.

$$
\text { Berdasarkan indikator }
$$
keberhasilan/indikator kinerja seperti tersebut di atas, dapat disimpulkan bahwa pada Siklus I penelitian dikatakan belum berhasil. Oleh karena itu kegiatan pembelajaran perlu dilanjutkan ke siklus II dengan perbaikan berdasarkan pengamatan kegiatan pembelajaran yang telah dilaksanakan pada siklus I.

\section{Pembahasan Siklus II}

Berdasarkan identifikasi langkahlangkah pembelajaran yang belum terlaksana dan kendala-kendala yang terjadi pada siklus I, peneliti 
melaksanakan beberapa perbaikan untuk kegiatan pembelajaran pada siklus II sehingga kegiatan pembelajaran pada siklus I yang belum terlaksana dapat dilaksanakan dengan baik pada siklus II dan target yang diharapkan dapat tercapai atau terlampaui semua. Kegiatan perbaikan pada siklus II dilakukan agar tanggung jawab, ketergantungan positif, partisipasi, dan keterampilan sosial siswa dalam kelompoknya dapat muncul secara maksimal. Kegiatan tersebut, diantaranya adalah sebagai berikut: (1) LKS dibagi kepada setiap siswa bukan hanya kepada setiap kelompok seperti pada siklus I, (2) alat peraga dibuat agar semua anggota kelompok terlibat dalam penggunaannya, (3) presentasi siswa dilakukan bergiliran untuk masingmasing anggota kelompok bukan hanya ketua kelompoknya saja, (4) tugas individu dikerjakan secara mandiri di buku tugas dan dikumpulkan di akhir pertemuan

Kegiatan pembelajaran pada siklus II dapat berjalan sesuai dengan rencana waktu yang tersedia dan sesuai dengan skenario pembelajaran yang telah direncanakan dalam RPP. Di awal siklus II masih terdapat kegiatan pembelajaran yang belum muncul pada diri siswa yaitu, tanggung jawab, ketergantungan positif antarsiswa, partisipasi dan keterampilan sosial siswa dalam kelompok. Siswa dengan kemampuan rendah masih menunggu jawaban dari siswa yang memiliki kemampuan tinggi. Sedangkan siswa dengan kemampuan tinggi mengerjakan LKS masih cenderung sendiri dan setelah selesai baru memberi tahu kepada teman sekelompoknya. Untuk mengatasi hal tersebut peneliti lebih menekankan pada bimbingan dan fasilitasi terhadap siswa dalam berdiskusi. Peneliti menekankan kembali kepada siswa bahwa pencapaian individu sangat mempengaruhi hasil kelompok karena penghargaan akan diberikan kepada kelompok yang memenuhi kriteria yang ditentukan.

Pemberian bimbingan, fasilitasi dan motivasi dari peneliti membuat siswa lebih bersemangat dan bersungguhsungguh dalam berdiskusi, kerja sama antaranggota kelompok tampak meningkat dan aktifitas pembelajaran lebih demokratis dan tidak lagi didominasi peneliti dan siswa yang pandai. Selain itu agar siswa lebih konsentrasi dan aktif, peneliti memancing siswa dengan pertanyaanpertanyaan terkait dengan LKS. Sementara pada kegiatan presentasi hasil penyelesaian tugas-tugas dalam LKS, peneliti memberikan motivasi kepada siswa agar lebih percaya diri dalam menyajikan atau memberi masukan/tanggapan dan menyampaikan kepada siswa bahwa keterampilan berkomunikasi sangat diperlukan di masa depan. Berdasarkan pengamatan peneliti, di akhir siklus II, kemampuan berkomunikasi siswa dalam presentasi dan memberi masukan/tanggapan dapat meningkat walaupun masih dengan bahasa yang cukup sederhana.

Di akhir siklus II dilakukan kegiatan kuis/ulangan harian. Pengamatan peneliti pada kegiatan kuis pada siklus II ini, siswa mulai berkonsentrasi dalam mengerjakan soal. Dalam mengerjakan soal siswa sudah tidak ramai lagi dan dikerjakan sendiri tanpa harus menengok teman. Nilai hasil kuis ini selanjutnya diolah untuk mendapatkan skor kemajuan individual masing-masing siswa. Kemudian dihitung rata-rata skor untuk setiap kelompok dan hasilnya untuk menentukan penghargaan kepada setiap kelompok berdasarkan 
kriteria yang telah ditentukan. Pemberian penghargaan dilaksanakan dengan memberikan piagam kepada kelompok yang mendapatkan kategori tim super. Pada siklus II semua kelompok mendapatkan penghargaan sebagai tim super.

Indikator keberhasilan/indikator kinerja pada siklus II dapat dirinci seperti berikut: (1) rata-rata hasil belajar siswa adalah 83 telah melampaui target yang diharapkan yaitu 72, (2) persentase siswa yang mencapai atau melampaui KKM adalah $80 \%$ telah melampaui target yang diharapkan yaitu $75 \%$, (3) rata-rata skor minat belajar matematika siswa adalah 94,25 (kategori tinggi) telah melampaui target yang diharapkan yaitu lebih dari 85 (kategori minimal tinggi), (4) persentase siswa yang memiliki skor minat belajar matematika kategori minimal tinggi (tinggi dan sangat tinggi) adalah $85 \%$ telah melampaui target yang diharapkan yaitu lebih dari $80 \%$, (5) rata-rata persentase keterlaksanaan pembelajaran menggunakan pembelajaran kooperatif tipe STAD mencapai 93,52\% termasuk ke dalam kriteria sangat baik, telah melampaui target yang ditentukan yaitu minimal kriteria baik.

Berdasarkan indikator keberhasilan/indikator kinerja seperti tersebut di atas, dapat disimpulkan bahwa pada siklus II penelitian dikatakan berhasil. Oleh karena itu kegiatan pembelajaran tidak perlu dilanjutkan ke siklus III.

\section{SIMPULAN DAN SARAN}

\section{Simpulan}

Berdasarkan hasil penelitian dapat disimpulkan bahwa: (1) pembelajaran kooperatif tipe STAD dapat meningkatkan hasil belajar matematika materi bangun ruang sisi lengkung pada siswa kelas IXA SMP Negeri 4
Bumijawa semester 1 tahun pelajaran 2017/2018, (2) pembelajaran kooperatif tipe STAD dapat meningkatkan minat belajar matematika materi bangun ruang sisi lengkung pada siswa kelas IXA SMP Negeri 4 Bumijawa semester 1 tahun pelajaran 2017/2018.

\section{Saran}

Berdasarkan hasil penelitian yang dilaksanakan, disampaikan saran-saran sebagai berikut: (1) pembelajaran kooperatif tipe STAD dapat meningkatkan hasil belajar dan minat belajar matematika pada materi bangun ruang sisi lengkung sehingga dapat diterapkan dalam kegiatan pembelajaran di kelas lain, (2) hasil penelitian dapat dijadikan referensi dan rujukan bagi guru lain jika ingin melakukan penelitian dengan topik yang sama, (3) perlu dilakukan penelitian menggunakan pembelajaran kooperatif tipe STAD untuk materi pelajaran matematika yang lain.

\section{REFERENSI}

Collete, A.T., \& Chiappetta, E.L. 1994. Science teaching in the middle and secondary schools (3rd ed). New York: Maxwell Macmillan, Inc.

Firmanto, I.A. \& Sapti, M. 2013. Meningkatkan minat dan hasil belajar matematika melalui metode STAD menggunakan LKS berbasis $P M R$. Diambil pada tanggal 30 Juli 2017, dari http://download. portalgaruda.org.

Hopkins, D. 2008. A Teacher's guide to classroom research. Berkshire: Open University Press.

Kemdikbud. 2014. Materi pelatihan implementasi kurikulum 2013 tahun 2014 mata pelajaran matematika 
SMP/MTs: untuk guru. Jakarta: Kemdikbud.

Mendikbud. 2014. Peraturan Menteri Pendidikan dan Kebudayaan Nomor 58, Tahun 2014, tentang Kurikulum 2013 Sekolah Menengah Pertama/Madrasah Tsanawiyah.

NCTM. 2000. Principles and standards for school mathematics. Reston, V.A: NCTM.

Nitko, A.J. \& Brookhart, S.M. 2011. Educational assesment of students. Boston: Pearson Education, Inc.

Sardin \& Sunandar, A. 2018. Pengaruh metode pembelajaran problem solving terhadap higher order thinking skill (HOTS) siswa kelas $X$ SMA Negeri 2 Baubau. Jurnal
THEOREMS (The Original Research of Mathematics), 3(2), 1-9.

Slameto. 2010. Belajar dan faktor-faktor yang mempengaruhi. Jakarta: PT Rineka Cipta.

Slavin, R. E. 2010. Cooperative learning: teori, riset, dan praktik. Bandung: Nusa Media.

Sutherland, R. 2007. Teaching for learning mathematics. New York: Open University Press.

Widoyoko, S.E.P. 2014. Evaluasi program pembelajaran: panduan praktis bagi pendidik dan calon pendidik. Yogyakarta: Pustaka Pelajar. 